\title{
歯周治療の長期観察について
}

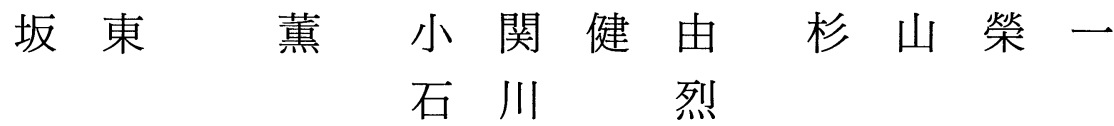 \\ 東京医科歯科大学歯学部歯科保存学第二講座 \\ (主任：石川 烈教授) \\ (平成 7 年 3 月 20 日受付)
}

\section{Long Term Observations of Periodontal Therapy}

\section{Kaoru BANDOH, Takeyoshi KOSEKI, Eiichi SUGIYAMA and Isao ISHIKAWA}

Department of Periodontology, Faculty of Dentistry, Tokyo Medical and Dental University

1-5-45, Yushima, Bunkyo-ku, Tokyo 113, Japan

(Chief : Prof. Isao ISHIKAWA)

The purpose of this study was to investigate the effect of periodontal treatment and maintenance therapy of 10 years duration. The study population consisted of 1 juvenile, 2 rapidly progressive and 43 adult periodontitis patients.

The average age of the patients was 42.3 years at the initial visit and the average duration of observation was 14.1 years. At the initial and most recent maintenance visits, the number of remaining teeth and the interproximal bone levels on X-ray films were measured. The average number of remaining teeth was 27.4 at baseline and 24.7 at final follow up. The total number of lost teeth during observation was 124 , that is 2.7 per individual. Four patients had lost more than 0.6 teeth per year, 5 patients had lost 0.3 to 0.6 teeth and 37 patients had lost less than 0.3. Twenty maxillary second molars and 18 mandibular third molars were extracted. The extractions were commonly located in the molar region and bilaterally symmetrical patterns of extraction were observed. Bone loss was observed in some regions of the mouth at the most recent visit. However, our data suggest that, despite slight bone loss, periodontal therapy was effective if maintenance therapy was correctly performed and that such treatment modalities facilitate reaching the goal of the " 8020 " movement.

Key words : Long term observations, Alveolar bone loss, Periodontal therapy

要旨：本研究では，10 年以上の歯周処置およびメインテナンス期間をもつ被験者を選び，X線写真を分析し， 歯周治療の長期経過を検討した。被験者は, 1 名の若年性歯周炎, 2 名の急速進行性歯周炎, 43 名の成人性歯周 炎患者であり, 初診時の平均年齢は 42.3 歳, 平均治療期間は 14.1 年であった。各歯の有無, および各歯の近遠 心面での骨吸収量を測定した。平均残存歯数は初診時が 27.4 歯，現在が 24.7 歯であった。年平均 0.6 歯以上覀 失した患者は 4 名, $0.3 \sim 0.6$ 歯は 5 名, 0.3 歯以下は 37 名であった。变失した歯種としては, 臼歯に多く, 左 右両側性の傾向がみられた。骨吸収量に関しては, 初診時に比べてメインテナンスの最終受診時において, ぞの 歯種でも有意に骨吸収は増加していた。しかしながら今回の結果より，歯周抢よび正しいメインテナンス治療を 行うことが成人の歯の保存に有用であり，そして“8020”の達成に有効であることが示唆された。

索引用語：長期観察, 歯槽骨吸収量, 歯周治療 


\section{緒言}

歯周疾患は, 成人の歯の喪失の最大の原因の一つで ある ${ }^{1)}$ 。歯科医が積極的にこの疾患の治療に取り組む ことにより，永久歯をより長期にわたって維持できる 可能性が高い。従って今後, 歯周治療が歯の保存に重 要な役割を果たすと思われる。現在，日本は世界でも 有数の長寿国となり，国民は今まで考えられなかった ような長い生涯を過ごすことが可能となった。しかし そのため Quality of Life の向上が同時に必要とされ， 厚生省は口腔保健の面から 80 歳で少なくとも 20 本を 保存しようという“8020”運動を提唱している。そこ で，これまで行われてきた歯周治療の長期にわたる効 果を調べる研究は有意義なものと思われるが，日本で はこのような報告はあまりみられない。そこで，10 年以上の治療期間をもつ被験者を無作為に選び $\mathrm{X}$ 線写 真を分析し，歯周治療とその後に続くメインテナンス 処置により歯がどのように保存されているかを追跡し た。

\section{材料および方法}

\section{1. 被験者}

東京医科歯科大学歯学部附属病院歯周病科に来院 し, 初期治療を含めて 10 年以上経過している患者を 無作為に選び被験者とした。被験者は，男性 14 名, 女性 32 名, 計 46 名, 初診時の平均年齢は 42.3 歳 （最年少 20.1 歳，最年長 62.8 歳）平均治療期間は 14.1 年（最短 10.3 年，最長 22.2 年）であった。若 年性歯周炎患者は 1 名, 急速進行性歯周炎患者は 2 名, 成人性歯周炎患者は 43 名であった。

\section{2. 歯周治療}

初診時の診査後, 口腔衛生指導, スケーリング, ルートプレーニングを主体とした初期治療を行った。
再評価後, 歯周ポケットが残存した部位には歯周外科 を行い, 約 3〜 6力月に一度の定期的なメインテナン スを行った。メインテナンス期間中は，口腔衛生指 導，歯肉縁上および縁下のデブライドメントを行っ た。

\section{X線写真の分析}

本研究では, 初診時およびメインテナンス期の最終 受診時のX線写真の分析を行った。X線は，本学歯学 部放射線科で，二等分面法により 10 枚法で撮影した。 診査項目は，歯の有無，および各歯の近遠心面での骨 吸収量の測定の二つとした。初診時と最終受診時の残 存歯数から，その間の抜歯数を算定し，経過年数で割 り，年平均抜歯数を算定した。骨吸収量の測定は 3 倍

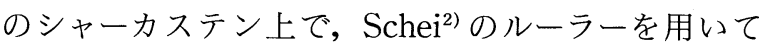
行った。なおこの測定は一人の術者が行った。初診時 と最終受診時での歯槽骨吸収の割合を比較した。年平 均抜歯数を 0 歯 $~ 0.3$ 歯, 0.3 歯 0.6 歯, 0.6 歯以上 に分け，それぞれ予後群として，良好群 (WM 群), 悪化群 ( $\mathrm{D}$ 群), 急速悪化群 (ED 群) とし, 各群ご との分析も行った。また，初診時と最終受診時の残存 歯数および年齢をもとに回帰直線を求め，80歳での 残存歯数を比例算出で予測した。統計処置として，各 群における年齢には $\mathrm{t}$ 検定を用い，各群における男女 の割合には Fisher の直接確率計算法，また初診時と 最終受診時の骨吸収量の比較には，Wilcoxon 検定を 用いた。

\section{結 果}

測定可能部位は 3532 部位 74\%，うち初診時と最終 受診時の比較可能部位は 2808 部位 $59 \%$ であった。初 診と最終受診時の間の抜歯数を経過年数で割った，年 平均抜歯数による被検者の分布をパーセンタイル表示 したものが，図 1 である。変曲点となる 0.3 本，およ びその倍の 0.6 本で区切ったところ, Hirschfeld と

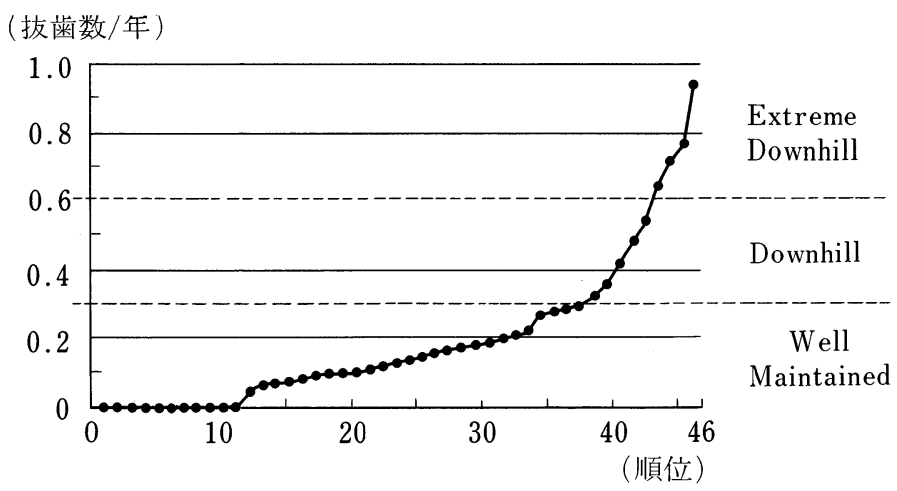

図 1 年平均抜歯数による被検者の分布 
表 1 各予後群毎のパラメータ

\begin{tabular}{|c|c|c|c|c|c|}
\hline 予後群 & 人数 & & & $\begin{array}{c}\text { 初診断齢 } \\
\text { (最小〜最大) }\end{array}$ & $\begin{array}{c}\text { 経過年数 } \\
\text { (最小〜最大) }\end{array}$ \\
\hline Extreme Downhill & 4 & 1 & 3 & $\begin{array}{c}41.0 \pm 13.1 \\
(28.9 \sim 59.3)\end{array}$ & $\begin{array}{c}16.6 \pm 3.4 \\
(14.6 \sim 21.7)\end{array}$ \\
\hline Downhill & 5 & 0 & 5 & $\begin{array}{c}37.7 \pm 9.3 \\
(26.9 \sim 47.4)\end{array}$ & $\begin{array}{c}14.9 \pm 3.0 \\
(11.0 \sim 17.8)\end{array}$ \\
\hline Well Maintained & 37 & 13 & 24 & $\begin{array}{c}43.1 \pm 11.0 \\
(20.1 \sim 62.8)\end{array}$ & $\begin{array}{c}14.7 \pm 2.6 \\
(10.3 \sim 22.2)\end{array}$ \\
\hline
\end{tabular}

$(\%) 100$

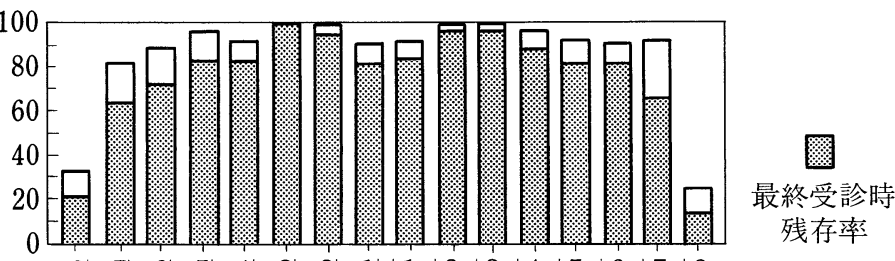

(\%) 100

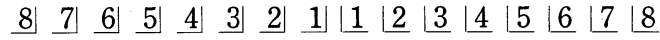

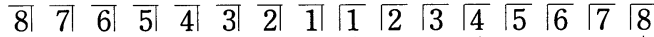

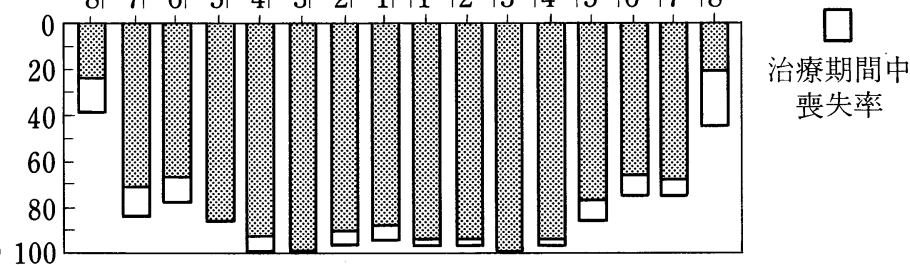

図 2 歯種別の残存率

Wasserman ら)の 10 本以上抜歯された Extreme downhill，4〜9 本抜歯された Downhill，および 3 本 まで抜歯されたWell maintainedの 3 群とほぼ一致 した。

初診時の平均年齢は $\mathrm{ED}$ 群が 41.0 歳, $\mathrm{D}$ 群が 37.7 歳, WM 群が 43.1 歳で， $\mathrm{t}$ 検定により，3 群の間に 有意な善は認められなかった。経渦年数は, ED群が 平均 14.9 年, D 群が 12.2 年, WM 群が 12.8 年で, やはり $\mathrm{t}$ 検定により 3 群の間に有意な差はなかった。 また，Fisherの直接確率計算法による各群の男女の 割合にも有意な差は認められなかった（表 1 ）。平均 残存歯数は初診時が 27.4 歯, 現在が 24.7 歯であり, この間の歯の賈失は全被験者の合計で 124 歯，すなわ ち被験者一人当りでは 2.70 歯, 年平均喪失歯数は 0.19 歯であった。また ED 群は 4 名, D 群は 5 名, WM 群は 37 名であった。

歯種ごとに残存率をみると, 犬歯を中心として左右 対称性が認められ, 大臼歯部に近づくに従い残存率が 下がる傾向がみられた（図 2 )。これを予後群ごとに みると, 初診時の残存率は, WM 群に比べD群, ED 群となるに従い低くなり, 現在の残存率はさらにその 傾向が顕著であった（図 3 )。治療期間中に抜歯した
歯数を術前の歯数で割つた喪失率を歯種ごとにみると 左右対称で，犬歯ではほとんど抜歯されておらず，犬 歯から離れるに従い抜歯される割合が高くなる傾向が みられた。第三大臼歯は最も喪失率が高く，上顎第二 大臼歯がそれに続いていた。また，第三大臼歯以外 は，下顎に比べ上顎の方が，喪失率が高くなる傾向が みられた。郭失した歯種〉しては，上顎第二大印歯が 20 歯, 下顎第三大臼歯が 18 歯であり, 臼歯に多く, 左右両側性の傾向がみられた（図 4 ）。

予後群別にみると，WM 群では臼歯部が抜歯され， $\mathrm{D}$ 群では喪失率が上がり小臼歯部にまでおよび，ED 群ではさらに前歯まで抜歯部位が広がっていた。犬歯 はどの群もほとんど抜歯されていなかった（図 5 )。

初診時，および初診より 10 年後の予測骨吸収量を 切歯, 犬歯, 小臼歯, 大臼歯の歯種ごとにみると, ぞ の歯種でも Wilcoxon 検定により，有意に骨吸収は増 していた。上下頡ともに, 切歯の骨吸収が，他の歯種 に比べ大きい傾向がみられた。また，上顎では，小臼 歯の骨吸収量が小さかった（図 6 ）。なお，初診より 10 年後の骨吸収量は, 治療期間中の骨吸収量を経過 年数で割り, 年平均骨吸収量を求め算出した。予後群 別では, WM 群に比べ, D 群の上顎および $\mathrm{ED}$ 群の 

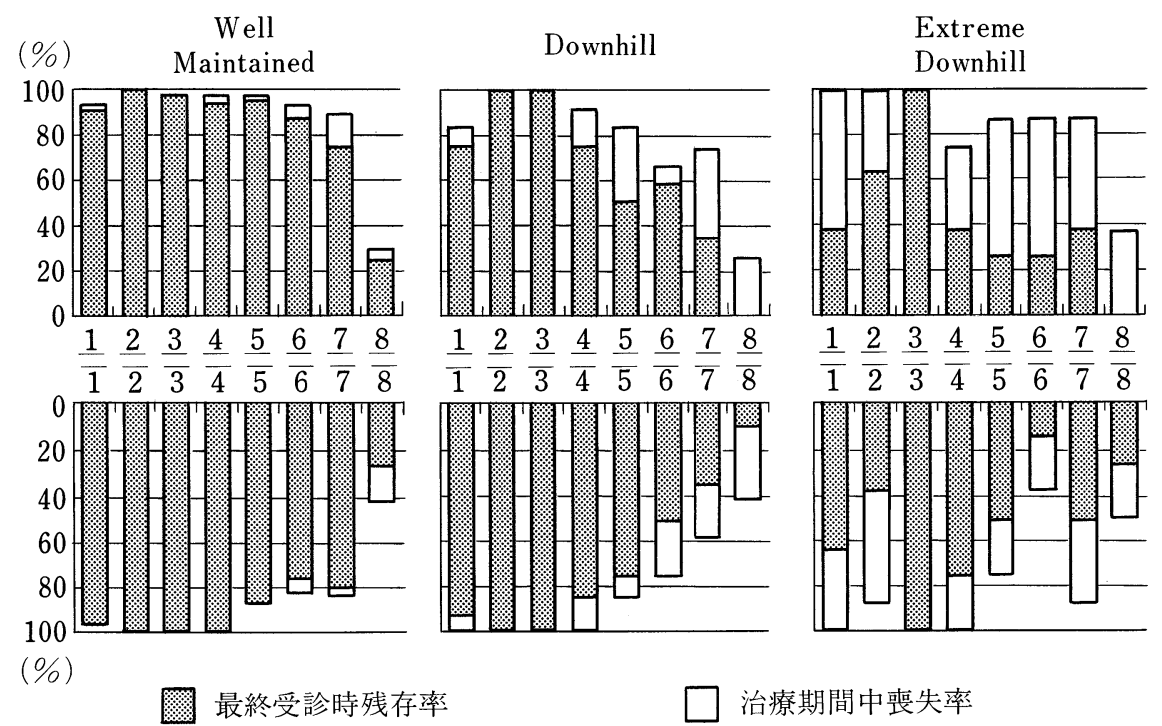

最終受診時残存率

治療期間中㷼失率

図 3 各予後群の歯種別の残存率

$(\%) 60$
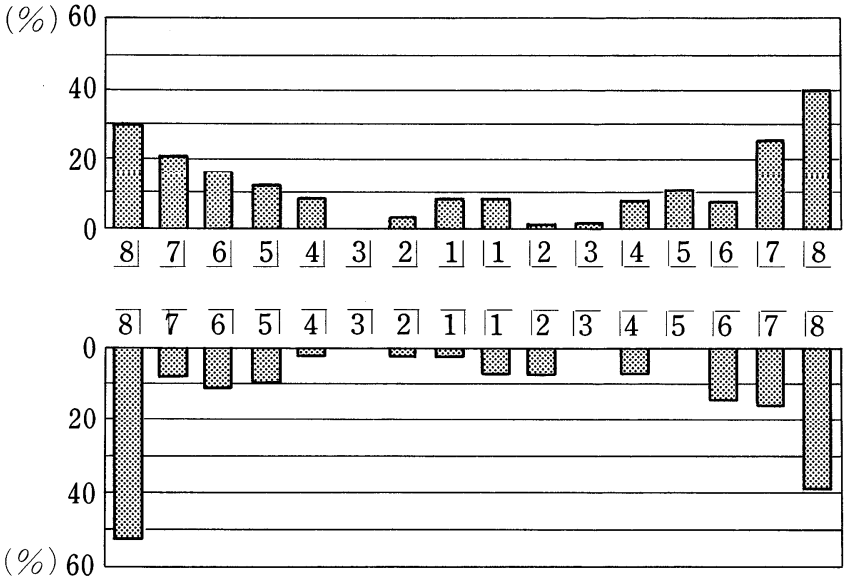

図 4 歯種別の喪失率

Well
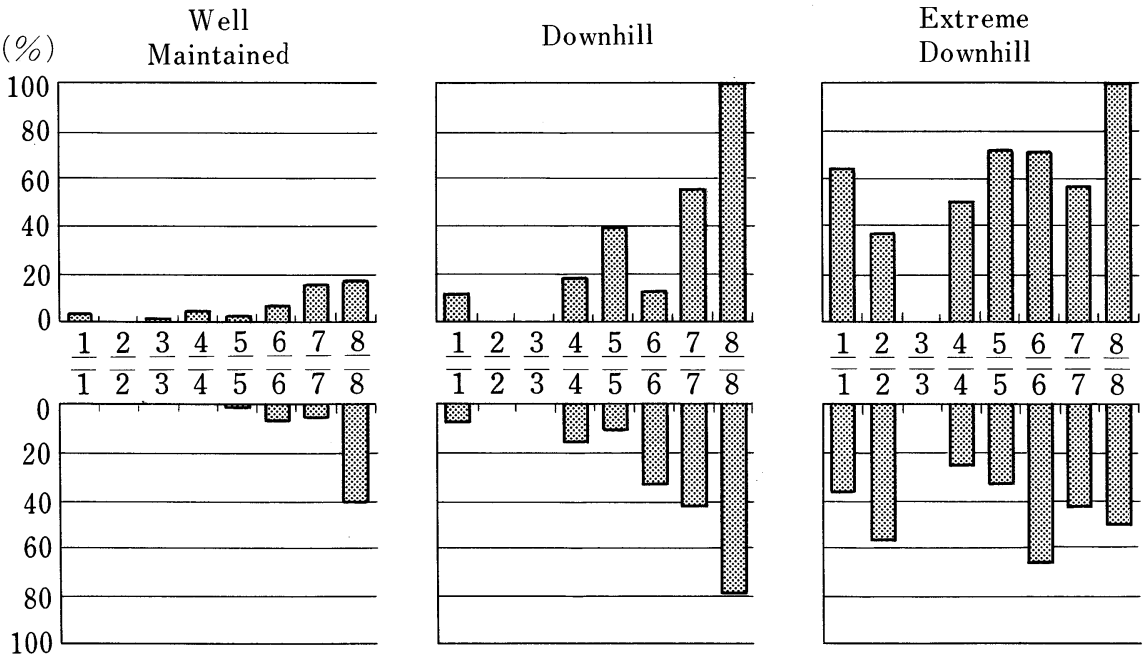

$(\%)$

図 5 各予後群の歯種別の喪失率 


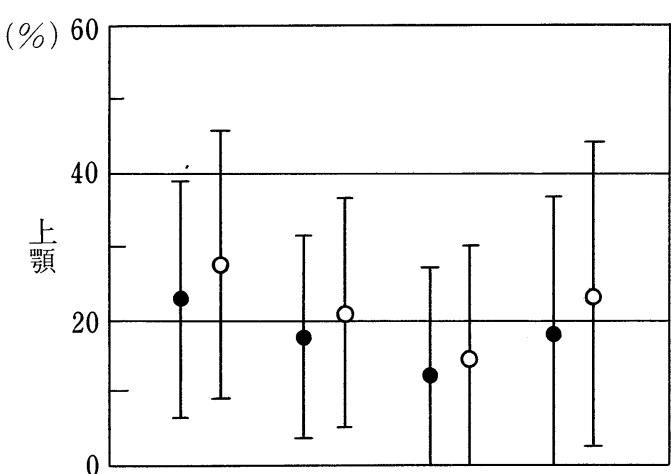

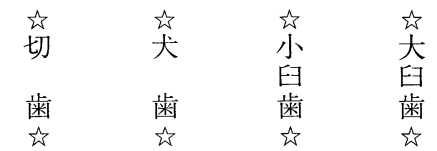
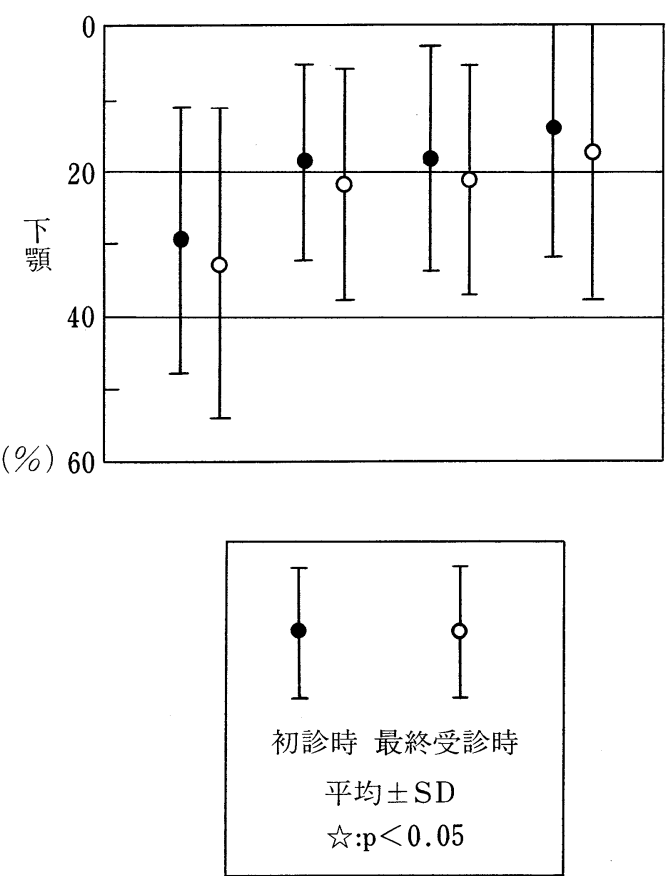

図 6 歯種別の初診時及び最終受診時の 骨吸収量の比較

上下顎は，骨吸収量の増加量が多い傾向が認められた (図 7 )。

初診時および最終受診時の, 残存歯数および年齢を もとに回帰直線を求め, 80 歳での残存歯数を比例算 出で予測したところ， 80 歳で 20 歯以上の残存歯が予 測される被験者は 46 名中 32 名で $65.2 \%$,すべて $\mathrm{WM}$ 群であった。一方, $\mathrm{ED}$ 群の 4 名中, 3 名は無歯 顎となることが予測された。本研究におけるすべての 被験者の, 80 歳での予測一人平均残存歯数は 20.2 歯 であった（図 8 )。

\section{考 察}

本研究は, 歯周処置およびメインテナンス治療の長 期にわたる経過を調べ，その効果を調べる目的で，10 年以上の治療期間をもつ被験者を選び, 初診時および メインテナンス最終受診時の X線写真を分析した。

今回，私共は分析にあたり，経過期間で割った年平 均喪失歯数により, 予後群を 3 つに分けた。これは被 験者の治療期間が 10.3 年 22.2 年と異なっていたた めである。メインテナンス期間中の経過を歯の有無で 追った Hirschfeld と Wasserman ${ }^{3)}$, McFall ${ }^{4}$, Gold-

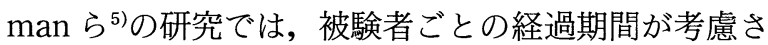
れていない。本研究の抜歯時期がカルテ上で明らかで あった被験者では, 初診時に近い時期に多くの歯が失 われているような傾向はみられなかった。したがっ て, 初診と最終受診の経過期閒を考慮にいれて年平均 の言失率を算定した今回の方法の方が，より正確な喪 失率を表しているものと思われる。一般には，歯周治 療では明らかに予後が不良と考元られる歯は, 早期に 抜歯されることが多いが，今回の調查ではできる限り 歯を保存するような処置がなされていたので, 長期観 察した結果 Hirschfeld と Wasserman ${ }^{3}$ の分類を行っ た場合とほほ同様の傾向を示した。

Becker $ら^{6}$ は, 歯周治療を受けなかった患者 29 名 の平均 3.7 年の経過を調べたところ, 年平均喪失歯数 は 0.61 歯であったと報告している。また Buckley と Crowley ${ }^{7)}$ は, 歯周治療を受けていない初診時平均年 齢 27.0 歳という比較的若年者 82 名を対象に経過をみ たところ, 年平均喪失歯数は 0.25 歯であったと報告 している。本研究の被験者では 0.19 歯と彼らの報告 よりは少なかった。また, 歯周治療を受けていない牛 久市民 243 名の 2 年間の変化をみた Lindhe $ら^{8)}$ の報 告では, 年平均喪失歯数は 0.17 歯であった。これは 一般市民を対象にしており, 本研究の被験者より, 歯 周組織の状態が良かったためであろう。また，メイン テナンス期間中の経過をみた Hirschfeld と Wasser$\mathrm{man}^{3)}$ の研究では年平均亦失歯数は 0.08 歯, McFall ${ }^{4)}$ らの研究では 0.14 歯, Goldman ら5の研究で は 0.16 歯であった。また Lindhe と Nyman ${ }^{9}$ は 0.04 歯とかなり少ない結果を報告している。これは,メイ ンテナンスに入るまでの抜歯基準の違いによるもの, すなわち彼らは，メインテナンスに入るまでにかなり の歯を抜歯したためと思われる。今回の私共のデー夕 は, 初診からの算定であり, 抜歯の必要な歯も含まれ ていたので，年平均の喪失歯が高まっていたと思われ る。 

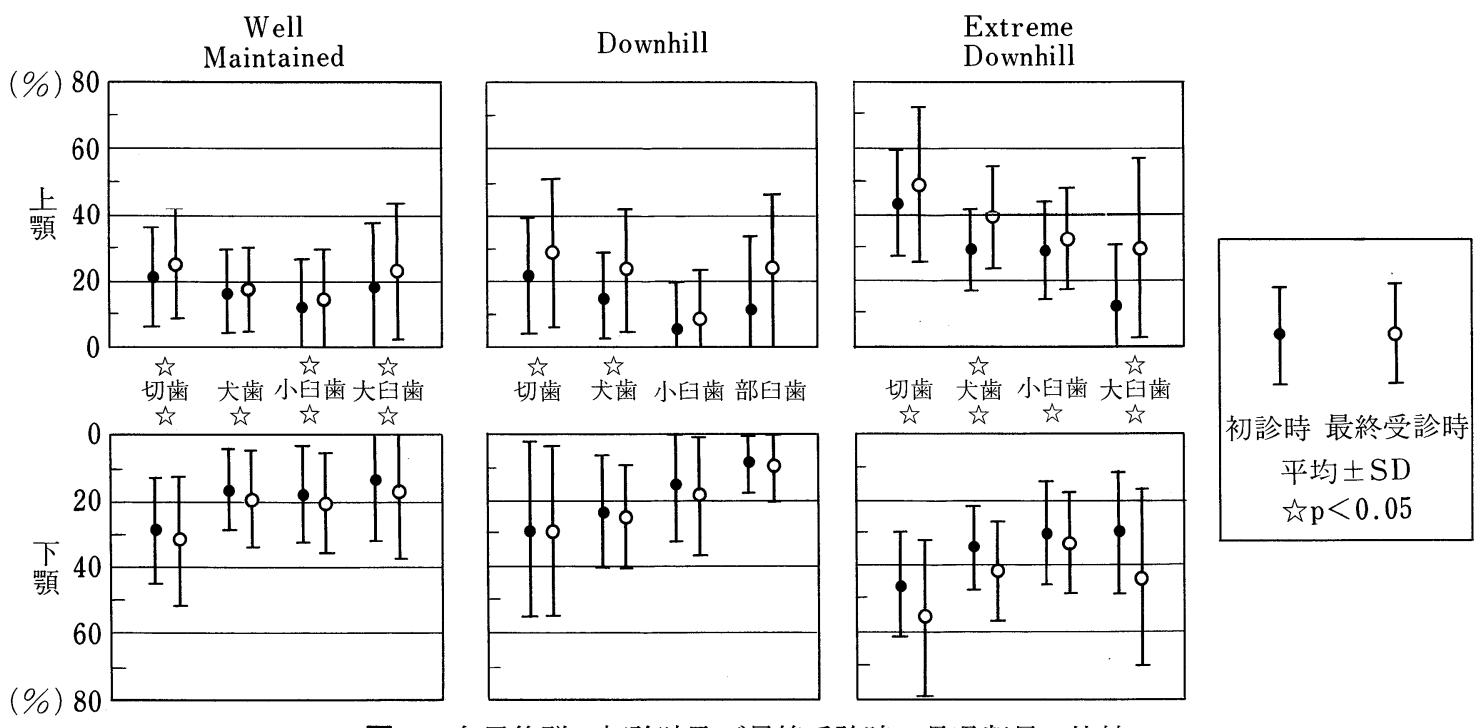

図 7 各予後群の初診時及び最終受診時の骨吸収量の比較
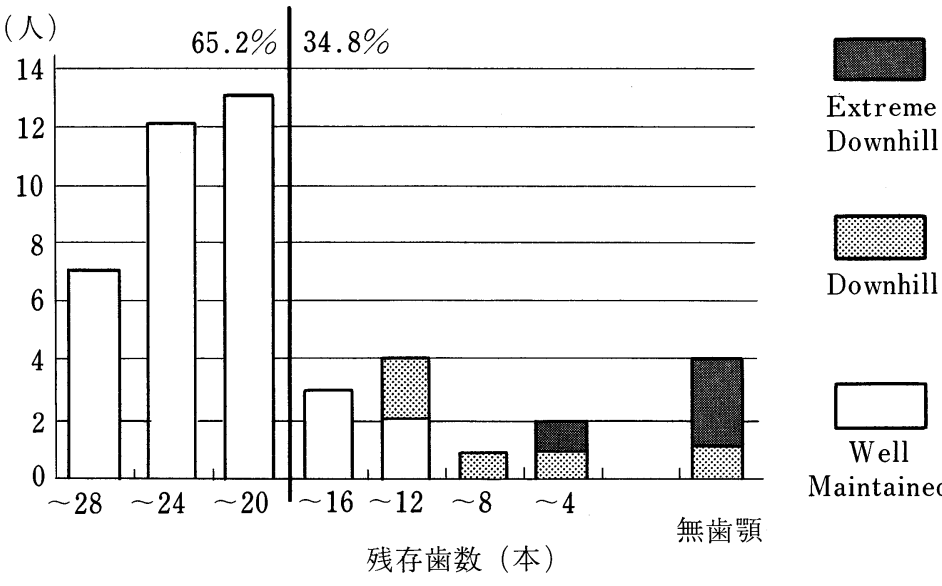

Extreme Downhill

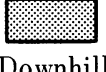

Downhill

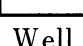

Maintained

図 880 歳時の予測残存歯数

Hirschfeld と Wasserman ${ }^{3)}$ の研究では，ED群は $4.2 \% ， \mathrm{D}$ 群は $12.6 \%$ WM 群は $83.2 \%$ であった。 $\mathrm{McFall}^{4)}$ はそれぞれ 8\%，15\%，77\%，Goldman ら5) は 10\%，28\%，62\%としている。本研究では，9\%， $11 \% ， 80 \%$ と彼らの数字と同様の傾向を示した。三 木ら ${ }^{10)}$ も 5 年以上のメインテナンス治療を受けている 患者を調べ，18.2\%の患者に，57.7\%の悪化部位が 集中していたと報告している。

本研究では, 智歯を除けば上顎大臼歯が最も喪失率 が高く, 続いて下䪽大臼歯, 上顎小臼歯の順で, 犬歯 は最も低かった（図 4)。同様の傾向は, Chace と Low $^{11)}$, Hirschfeld と Wasserman ${ }^{3)}, \mathrm{McFal1}^{4)}$, Goldman ら ${ }^{5)}$ も認めている。これは, 島内ら ${ }^{12)}$ 分岐 部病変が存在する大臼歯部に歯周疾患の再発が多いこ とを報告しているように，分岐部病変，歯根長などの
解剖学的形態が，歯周治療の悪化に関与しているもの と思われる。

また 3 群共に，同様な傾向が見られたが，犬歯以外 WM 群, $\mathrm{D}$ 群, ED 群となるに従い, 喪失率が増して いた（図 3，5）。これは Hirschfeldと Wasserman ${ }^{3)}$ が述べている様に, それぞれの歯の予後は, その時点 での重症度と共に, 各患者ごとの衰失傾向により決ま るためと思われる。

Hirschfeld とWasserman ${ }^{3)}$ の報告では，初診時の 重度の歯周炎患者の割合は, 3 群間で差はなかったと している。しかし，本研究の初診時の骨吸収量でみる と, 特に ED 群では, 上顎大臼歯以外, ぞの歯種でも 骨吸収が，他の 2 群に比べ，多い傾向が認められた (図 7 )。これは骨吸収量の方がより詳細にその時点で の歯周組織の状態を示しているためと思われる。 
さらに，本研究で明らかになったこととして， WM 群では第三大臼歯を除いてほとんどの歯が 10 年 以上維持された。それに対して, 症例は少ないが, ED 群では，犬歯を除いてほとんどの歯種の賈失が約 40〜 70\% 程度まで進んでいた。D群はほぼその中間 型をとっているように思われた。ここで行われた治療 法は非特異的なプラークコントロール，初期治療，歯 周外科という基本的な方法に基づいて行われた。しか しながら，ED群やD群ではこの方法がかならずしも 良くないことを示している。歯周病変の進行はポケッ 卜内細菌叢の面からと生体側の因子の両面から考える 必要があろう。例えば, 細菌叢から考慮するとActinobacillus actinomycetemcomitans が従来の方法では除 けないことが知られてきており, Porphyromonas gingivalis が分岐部に多いことも知られはじめた。こ のような歯周病原性細菌の消長を歯周治療に取り入れ る必要性が考えられる。一方, 生体側の因子では, 白 血球機能，免疫機能の解析が不可欠であることがこれ までも指摘されていた。今後 ED 群やD群でこれらの どれが最も作用しているかを明らかにし, 歯周治療の 精度を高める必要がある。

初診時とメインテナンス最終受診時の骨吸収量を比 較したところ，どの歯種でも骨吸収量の増加がみられ た（図 6 )。すなわちメインテナンス治療をしても 10 年以上の経過ではわずかでも骨吸収が進行することが 認められた。定期的なメインテナンスを受けていない 23 名の被験者の平均 5.4 年の経過を追った DeVore $ら^{13)}$ は下顎大臼歯部にのみ骨吸収が顕著であったとし ている。これは期間が短かったためか, 統計方法の違 い(本研究では初診時, 最終受診時で対応をつけた $\mathrm{t}$ 検定を行った）によるものと思われる。

初診時およびメインテナンス最終受診時の, 残存歯 数および年齢から予測した 80 歳での一人平均残存歯 数は, 20.2 歯であった。現在の 80 歳での一人平均残

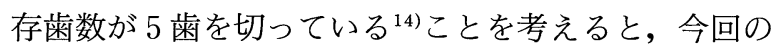
結果より，歯周治療を行うことが成人の歯の保存，ひ いては“8020”の達成に有効であることが示唆され た。しかし他方, 現在のような器械的なブラッシング やスケーリングを中心とした歯周治療を行っても歯の 喪失は防げず，“8020”を達成できない人のいること もまた，示唆された。その人々の歯の喪失を止めるに は, 歯周病原性細菌の同定やその除去, 生体側の防御 因子の確定とそれに対する有効な処置法は何かを見つ けだす努力と, どのような生活習慣や口腔清掃法, 咬 合関係が有効なのか, 今後さらなる検討が必要であろ う。

\section{結＼cjkstart論}

本研究では, 歯周治療の効果をみる目的で, 10 年 以上の治療期間をもつ被験者 46 名の初診時とメイン テナンス最終受診時の X 線写真を分析し, 以下の結論 を得た。

1. 平均残存歯数は初診時が 27.4 歯, 現在が 24.7 歯で，この間の歯の喪失は患者一人当たりでは 2.70 歯であった。年平均 0.6 歯以上喪失した患者は 4 名, $0.3 \sim 0.6$ 歯は 5 名, 0.3 歯以下は 37 名であった。

2. 歯の喪失は両側性に生じ, 下頡に比べ上顎が多 く,また大臼歯部が最も多く, 犬歯が最も少なかっ た。

3. 骨吸収量は, どの歯種でも有意に増加してい た。

4. それにもかかわらず，歯周治療およびメインテ ナンス治療を行うことで, 本研究の範囲内での 80 歳 の予測一人平均残存歯数は 20.2 歯で, 歯周治療を行 うことが成人の歯の保存そして“8020”の達成に有効 であることが示唆された。

\section{文献}

1） 藤田 勝, 加藤増夫, 後藤 勉, 橋本 弘, 根岸達 朗, 小村和孝, 柏木 勝, 白勢康夫：神奈川県にお ける拔歯の原因 第二報. 口腔衛生会誌, 40：382383, 1991.

2) Schi, O., Waerhaug, J., Lovdal, A. and Arno, A. : Alveolar Bone Loss as Related to Oral Hygiene and Age. J. Periodontol. $30: 7-16,1959$.

3) Hirschfeld, L. and Wasserman, B. : A Long-Term Survay of Tooth Loss in 600 Treated Periodontal Patients. J. Periodontol. 49 : 225-237, 1978.

4) McFall, W.T. : Tooth Loss in 100 Treated Patients With Periodontal Disease: J. Periodontol. $53: 539-549,1982$.

5) Goldman, M.J., Ross, I.F. and Goteiner, D. : Effect of Periodontal Therapy on Patients Maintained for 15 Years or Longer. J. Periodontol. 57 : 347353, 1986.

6) Becker, W., Berg, M.L. and Becker, B.E. : Untreated periodontal disease: A Longitudinal study. $50: 234-244,1979$.

7) Buckley, L.A. and Crowley, M.J. : A longitudinal study of untrested periodontal disease. J. Clin. Periodontol. $11:$ 523-530, 1984.

8) Lindhe, J., Okamoto, H., Yoneyama, T., Haffajee, A. and Socransky, S.S. : Longitudinal changes in 
periodontal disease in untreated subjects. J. Clin. Periodontol. 16 : 662-670, 1989.

9) Lindhe, J. and Nyman, S. : Long-term maintenance of patients treated for advanced periodontal disease. J. Clin. Periodontol. $11: 504-514$, 1984.

10）三木靖夫，大竹 毅，島袋善夫，北村正博，島内英 俊, 村上伸也, 岡田 宏: 長期経過症例における歯 周病ハイリスク患者の検討. 日歯周誌, $35 ： 409$ 416, 1993.

11) Chace, R. and Low, S.B. : Survival Characteristics of Periodontally-Involved Teeth : A 40-Year Study. J. Periodontol. 64 : 701-705, 1993.
12）島内英俊，三木靖夫，大竹 毅，藤本玲子，北村正 博，島袋善夫，岡田 宏：長期経過症例における歯 周外科処置の臨床的評価（第 2 報）歯周外科処置部 位の経過に影響を与える因子，日歯保誌，37：1552 -1558, 1994.

13) DeVore, C.H., Duckworth, J.E., Beck, F.M., Hicks, M.J., Brumfield, F.W. and Horton, J.E. : Bone Loss Following Periodontal Therapy in Subjects without Frequent Periodontal Maintenance. J. Periodontol. 57 : 354-359, 1986.

14）厚生省健康政策局歯科衛生課：62 年歯科疾患実態 調査報告. 口腔保健協会, 東京：29-30, 1989.

\section{連絡先：}

東京医科歯科大学歯学部歯科保存学第二講座

T 113 文京区湯島 1-5-45 